\title{
DUGAAN PENGANIAYAAN TERHADAP TERSANGKA DALAM PROSES PENYIDIKAN DARI PERSPEKTIF HUKUM ACARA PIDANA DAN KONSEKUENSI HUKUM YANG PATUT DITERIMA OLEH PARA PELAKU
}

\author{
Oleh \\ Dippo Alam*)
}

\section{Abstrak}

Beberapa waktu belakangan ini, terjadi beberapa penganiayaan yang dilakukan oleh penyidik kepada tersangka tindak pidana. Penyiksaan terhadap para terdakwa selama proses penangkapan bukanlah suatu hal baru di dalam proses penegakan hukum di Indonesia. Berdasarkan temuan LBH Jakarta dalam mendampingi kasus penyiksaan di sepanjang tahun 2013 s.d. 2016, pada umumnya penyiksaan terjadi pada tahap awal penyidikan yaitu pada tahap mengumpulkan alat bukti. Penyiksaan yang dilakukan dengan latar belakang untuk mengejar pengakuan dari seorang tersangka mencerminkan kurangnya pengetahuan dan pemahaman dari aparat Kepolisian terhadap ketentuan hukum acara pidana. Walaupun KUHAP dikatakan amat menghormati hak-hak tersangka/terdakwa, tindak kekerasan dalam penyidikan masih saja terjadi. Polisi masih menggantungkan proses penyidikan pada keterangan tersangka. Pengungkapan suatu tindak pidana tidak mempedomani pengakuan Tersangka tetapi yang terpenting adalah memperoleh alat-alat bukti. Terhadap penyidik yang melakukan penganiayaan, jika memang terbukti, hendaknya diberi sanksi etik dan juga sanksi pidana sesuai peraturan perundang-undangan yang berlaku. Hal ini untuk menciptakan rasa keadilan dan mengkondusifkan proses penyidikan selanjutnya. Banyak cara yang dapat ditempuh untuk mendapatkan keterangan tersangka dengan baik dan bermartabat. Salah satu caranya adalah dengan melakukan pendekatan secara psikologis. Diperlukan adanya pelatihan dasar mengenai psikologi kriminal bagi para penyidik untuk membaca keadaan jiwa pelaku tindak pidana, atau dapat juga bekerjasama dengan psikolog atau psikiater untuk membantu proses penyidikan yang bersih dan manusiawi.

\section{Kata Kunci : Penganiayaan, Penyidik, Tersangka, Psikologis}

\section{A.PENDAHULUAN}

Beberapa waktu belakangan ini, terjadi beberapa penganiayaan yang dilakukan oleh penyidik kepada tersangka tindak pidana. Salah satunya adalah dugaan penganiayaan yang dilakukan penyidik kepada Dede Lutfi Alfiandi dalam

*) Penulis adalah Dosen Fakultas Hukum Universitas Islam Syekh Yusuf perkara aksi demonstrasi yang bertajuk Reformasi Dikorupsi. ${ }^{1}$

Menurut hipotesis awal penulis, penganiayaan yang dilakukan oleh penyidik dimaksudkan untuk menggali keterangan

1 Riyan Setiawan, (2020-01-22). Kesaksian Lutfi Dianiaya Penyidik: Bukti Polisi Humanis Cuma Jargon. Tirto.id. https://tirto.id/ kesaksian-lutfi-dianiaya-penyidik-buktipolisi-humanis-cuma-jargon-et6L diakses tanggal 24 Februari 2020 
tersangka dalam proses pem-buatan Berita Acara Pemeriksaan. Hipo-tesis awal ini penulis pakai setelah mengkaji kasus salah tangkap tindak pidana pembunuhan yang dilakukan oleh terdakwa (Fikri, Pau, Fata, dan Ucok), berdasarkan isi surat dakwaan, perbuatan terdakwa dilakukan karena ketidaksukaannya kepada korban yang tidak menunjukkan rasa hormat sebagai pengamen baru di wilayah Cipulir. ${ }^{2}$ Hal yang menarik dalam kasus ini adalah ketika para Terdakwa mencabut segala keterangan mereka di Berita Acara Pemeriksaan (BAP). ${ }^{3}$ Mereka mengaku di persidangan bahwa mereka disiksa dan dipaksa untuk mengaku sebagai pelaku ketika diperiksa oleh para penyidik. ${ }^{4}$ Selain itu ada juga keterangan dari saksi yang menyatakan bahwa pelaku pembunuhan terhadap korban bukanlah para Terdakwa. ${ }^{5}$

Penyiksaan terhadap para terdakwa selama proses penangkapan bukanlah suatu hal baru di dalam proses penegakan hukum di Indonesia. 6 Menurut penelitian Lembaga Bantuan Hukum Masyarakat menemukan adanya 228 dari 388 responden yang mengalami penyiksaan saat ditangkap oleh pihak penyidik. ${ }^{7}$

KUHAP memberi definisi penyidikan sebagai berikut ${ }^{8}$ :

"Serangkaian tindakan penyidikan dalam hal dan menurut cara yang

2 Dio Ashar Wicaksana, Penyiksaan Penyidik terhadap Terdakwa untuk Mendapatkan Pengakuan, Anotasi Putusan, No. Register Perkara 1131/Pid. An/2013/PN.Jkt.Sel, MaPPI FHUI, 2016, hal. 5.

3 Ibid.

4 Ibid.

5 Ibid.

6 Ibid.

7 Ibid.

8 Andi Hamzah, Hukum Acara Pidana Indonesia, Edisi Kedua. Cet. 8. Jakarta. Sinar Grafika. 2017, hal. 120. diatur dalam undang-undang ini untuk mencari serta mengumpulkan bukti yang dengan bukti itu membuat terang tentang tindak pidana yang terjadi dan guna menemukan tersangkanya."

Deklarasi Universal Hak Asasi Manusia menyatakan bahwa Hak Asasi Manusia haruslah dilindungi. 9 Secara umum, International Bill of Human Rights terdiri dari Deklarasi Universal Hak Asasi Manusia, Kovenan Internasional Hak Sipil dan Politik, beserta dua optional protocolnya, dan Kovenan Internasional Hak Ekonomi, Sosial, dan Budaya. Selanjutnya terkait dengan isu anti penyiksaan, maka ketentuan yang relevan adalah Pasal 5 yang berbunyi "Tidak seorang pun boleh disiksa atau diperlakukan secara kejam, diperlakukan atau dihukum secara tidak manusiawi atau dihina". 10

Dalam tahap penyidikan Polisi kerapkali melakukan praktek-praktek penyiksaan terhadap seorang tersangka dengan tujuan untuk menggali keterangan atau memaksa seorang tersangka di bawah kuasanya untuk mengakui suatu perbuatan yang mana perbuatan tersebut belum tentu orang tersebut lakukan. Tindakan penyiksaan tersebut seolah telah menjadi kebiasaan untuk mempermudah proses penyidikan. ${ }^{11}$

Berdasarkan temuan LBH Jakarta dalam mendampingi kasus penyiksaan di sepanjang tahun 2013 s.d. 2016, pada umumnya penyiksaan terjadi pada tahap awal penyidikan yaitu pada tahap mengumpulkan alat bukti. 12 Penyiksaan yang dilakukan dengan latar belakang

9 Ayu Eza Tiara, dkk., Kepolisian dalam Bayang-Bayang Penyiksaan (Catatan Kasus Penyiksaan Sepanjang Tahun 2013 s.d. 2016. Jakarta. Lembaga Bantuan Hukum Jakarta. Tanpa tahun, hal. 25.

10 Ibid.

11 Ibid., hal. 62.

12 Ibid., hal. 63. 
untuk mengejar pengakuan dari seorang tersangka mencerminkan kurangnya pengetahuan dan pemahaman dari aparat Kepolisian terhadap ketentuan hukum acara pidana. Praktek penyiksaan juga diperparah dengan rendahnya kemampuan Kepolisan dalam mengungkap dugaan tindak pidana. ${ }^{13}$

Penyiksaan memang kerap dijadikan cara untuk mempermudah penyidik dalam memperoleh pengakuan atau keterangan dari seorang tersangka atau bahkan saksi. ${ }^{14}$ Tidak jarang Jaksa dan Hakim menganggap penyiksaan adalah hal yang biasa. Mereka menutup mata dengan adanya praktek penyiksaan tersebut. 15

Tidak dapat dipungkiri bahwa sebagian besar pelaku penyiksaan di Indonesia adalah polisi, karena memang Polisi lah yang mempunyai peran penting dalam tahapan penyidikan yang merupakan salah satu tahap awal dari berjalannya peradilan pidana, bahkan Institusi Kepolisian sendiri juga mengakui bahwa tingkat tindak penyiksaan pada Kepolisian masih sangat tinggi. ${ }^{16}$

Selain tingkat pendidikan yang mungkin mengakibatkan terus terjadinya praktek penyiksaan, penindakan terhadap aparat Kepolisian pelaku penyiksaan cenderung lemah. ${ }^{17}$ Penindakan yang lemah sepertinya berbanding lurus dengan belum adanya peraturan khusus mengenai penyiksaan yang diatur di Indonesia, sehingga tidak ada upaya pencegahan serta penegakkan terhadap tindak pidana penyiksaan. ${ }^{18}$

\footnotetext{
13 Ibid.

14 Ibid., hal. 70.

15 Ibid., hal. 71.

16 Ibid., hal. 74.

17 Ibid., hal. 75.

18 Ibid.
}

\section{B. PEMBAHASAN}

Definisi Pembuktian dan Teori Pembuktian Berdasarkan Undang-Undang Secara Negatif, Serta Kedudukan Keterangan Terdakwa Sebagai Salah Satu Alat Bukti Dalam Hukum Acara Pidana

Pembuktian dalam perkara pidana adalah untuk membuktikan adanya tindak pidana dan kesalahan terdakwa. Dalam praktik pembuktian adalah tindakan penuntut umum untuk menciptakan keyakinan hakim yang diperoleh dari alat bukti minimum tentang adanya tindak pidana dan bahwa terdakwalah yang bersalah melakukannya. ${ }^{19}$

Teori pembuktian berdasarkan undang-undang secara negatif menyatakan bahwa pembuktian harus didasarkan kepada ketentuan undang-undang dan keyakinan hakim, yaitu sekurang-kurangnya adanya dua alat bukti yang sah dan keyakinan hakim yang diperoleh dari sekurang-kurangnya dua alat bukti yang sah. ${ }^{20}$ Teori ini diterapkan di negara kita sebagaimana terbaca dalam pasal 183 KUHAP. 21

Menurut pasal 184 (1) KUHAP, alat bukti yang sah ialah: 22

a. Keterangan saksi

b. Keterangan ahli

c. Surat

d. Petunjuk

e. Keterangan Terdakwa

Yang dimaksud dengan saksi adalah orang yang dapat memberikan keterangan guna kepentingan penyidikan, penuntutan, dan peradilantentang suatu perkara

19 Hendar Soetarna, Hukum Pembuktian dalam Acara Pidana, Cet. 3. Bandung. Alumni. 2019, hal.9.

20 Ibid., hal. 41.

21 Ibid.

22 Undang-Undang No. 8 Tahun 1981 tentang Hukum Acara Pidana. 
pidana yang ia dengar sendiri, ia lihat sendiri, dan ia alami sendiri. ${ }^{23}$ Maka dari itu, baik pendapat maupun rekaan yang ia peroleh dari hasil pemikiran saja, bukan merupakan keterangan saksi. ${ }^{24}$

Berkaitan dengan asas unus testis nullus testis (satu saksi, bukan saksi), apa yang dikemukakan R. Subekti terasa lebih gamblang:

"Ketentuan-ketentuan dalam Hukum Acara Pidana yang menetapkan bahwa kesaksian satu orang saksi, yang tidak dikuatkan oleh lain-lain alatalat bukti, tidak dapat berlaku sebagai bukti yang sah."25

Dalam pasal 1 angka 28 KUHAP disebutkan:

"Keterangan ahli adalah keterangan yang diberikan oleh seseorang yang memiliki keahlian khusus tentang hal yang diperlukan untuk membuat terang suatu perkara pidana guna kepentingan pemeriksaan". ${ }^{26}$

Ketentuan tentang keterangan ahli adalah keterangan yang dinyatakan di dalam sidang pengadilan. 27 Keterangan ahli yang dinyatakan dalam sidang pengadilan merupakan alat bukti sebagaimana dimaksud dalam pasal 184 KUHAP, sedangkan keterangan ahli di luar pengadilan, yang berbentuk tulisan, atau yang dikenal sebagai "Visum et Repertum (VER)" berkualifikasi sebagai alat bukti surat. ${ }^{28}$

Yang dimaksud dengan ahli merujuk pasal 133 (1) KUHAP:

"Dalam hal penyidik untuk kepentingan peradilan menangani seorang korban baik luka, keracunan atau

23 Ibid., pasal 1 angka 26, dan Hendar Soetarna, op. cit., hal. 48.

24 Ibid., Pasal 185 (5), dan Hendar Soetarna, ibid.

25 Hendar Soetarna, Ibid., hal. 62.

26 Ibid., hal. 69.

27 Ibid.

28 Ibid. pun mati yang diduga karena peristiwa yang merupakan tindak pidana, ia berwenang mengajukan permintaan keterangan ahli kepada ahli kedokteran kehakiman atau dokter dan atau ahli lainnya."29

Pengertian apa dan siapa ahli, kiranya akan lebih jelas jika mengutip California Evidence Code sebagaimana dikutip Andi Hamzah, yang menyebutkan:

"Seseorang dapat memberi keterangan sebagai ahli jika ia mempunyai pengetahuan, keahlian, pengalaman, latihan, atau pendidikan khusus yang memadai untuk memenuhi syarat sebagai seorang ahli tentang hal yang berkaitan dengan keterangannya."30

Menurut penulis, pengetahuan, keahlian, pengalaman, latihan, atau pendidikan khusus ini harus dapat dilaksanakan secara ilmiah dengan dilakukannya pengajaran dan penelitian-penelitian secara empiris di dalam semua lembaga pendidikan formal yang diakui oleh negara.

Alat bukti selanjutnya adalah alat bukti surat. Menurut Sudikno Mertokusumo, alat bukti tertulis atau surat adalah segala sesuatu yang memuat tanda-tanda bacaan yang dimaksudkan untuk mencurahkan isi hati atau untuk menyampaikan buah pikiran seseorang dan dipergunakan sebagai pembuktian. ${ }^{31}$

KUHAP tidak menjelaskan apa yang dimaksud surat, hanya mengemukakan surat sebagai alat bukti adalah surat yang dibuat atas sumpah jabatan atau dikuatkan dengan sumpah. ${ }^{32}$

Menurut Hendar Soetarna, alat bukti petunjuk terwujud karena adanya persesuaian perbuatan, kejadian, atau keadaan satu sama lain maupun dengan tindak pidana itu sendiri. ${ }^{33}$ Perbuatan, kejadian

29 Ibid., hal. 70.

30 Ibid., hal. 71-72.

31 Ibid., hal. 73.

32 Ibid., hal. 74.

33 Ibid., hal. 75. 
atau keadaan bertalian dengan alat bukti petunjuk adalah "fakta hasil pembuktian dari pemeriksaan persidangan" yang didukung oleh alat-alat bukti.

Alat bukti keterangan terdakwa ditempatkan di urutan terakhir. Penempatan tersebut dimaksudkan agar terdakwa terlebih dahuku mendengar, melihat alat bukti yang lain, dan telah diperlihatkannya barang bukti. ${ }^{34}$ Diharapkan terdakwa benar-benar dapat merenungi, menyadari apa yang didakwakan, meskipun bukan berarti terdakwa harus membenarkan atau mengiyakan setiap alat bukti yang dikemukakan dalam sidang. 35

Pentingnya keterangan terdakwa sebagai alat bukti tidak diragukan, karena dialah yang dipandang paling mengetahui, karena dialah yang benar-benar mengalami tindak pidana yang didakwakan. Didorong pandangan demikian, maka ada pandangan perlunya "pengakuan" dari terdakwa dan dengan pengakuan akan memudahkan pembuktian. 36

Tidak jarang terdakwa dalam persidangan menyatakan bahwa apa yang ia nyatakan dalam berkas perkara bukanlah pernyataan sebenarnya, tetapi pernyataan yang terpaksa karena tidak mampu menghadapi tekanan dari pemeriksa baik secara mental maupun fisik. ${ }^{37}$

Dalam hal terdakwa mengakui apa yang didakwakan, dan tidak ada alat bukti lainnya, bukan berarti telah terbuka kemungkinan penjatuhan pidana karena pasal 189 (4) KUHAP menyatakan:

"Keterangan terdakwa saja tidak cukup untuk membuktikan bahwa ia bersalah melakukan perbuatan yang didakwakan kepadanya, melainkan harus disertai alat bukti yang lain."38

\footnotetext{
34 Ibid., hal. 79.

35 Ibid.

36 Ibid.

37 Ibid.

38 Ibid., hal. 80.
}

Pasal tersebut merupakan upaya jangan sampai ada keterangan terdakwa yang direkayasa. ${ }^{39}$ Berkaitan dengan keterangan terdakwa, ialah apa yang terdakwa nyatakan di sidang tentang perbuatan yang ia lakukan atau yang ia ketahui sendiri atau alami sendiri. 40 Apabila keterangan terdakwa berbeda dengan berkas perkara, maka Yurisprudensi berdasar Putusan Mahkamah Agung R.I. tanggal 23 Februari 1960 Nomor 299K/KR 1959 menyatakan:

"Pengakuan terdakwa di luar sidang yang kemudian di sidang pengadilan mencabut tanpa alasan yang berdasar merupakan petunjuk tentang kesalahan terdakwa."41

Pada akhirnya, dalam pasal 52 KUHAP menyatakan:

"Dalam pemeriksaan pada tingkat penyidikan dan pengadilan, tersangka atau terdakwa berhak memberikan keterangan secara bebas kepada penyidik atau hakim." 42

Menurut penulis, kata bebas di atas berarti tersangka atau terdakwa dapat dengan leluasa memberikan keterangan kepada penyidik atau hakim tanpa mengalami tekanan fisik maupun mental, berdasarkan persesuaian dengan alat bukti yang lain. Apabila tersangka atau terdakwa dianggap tidak mau memberikan keterangan, bukan berarti tersangka harus ditekan, melainkan penyidik harus mampu menggali bukti-bukti lain berdasarkan empat alat bukti selain keterangan terdakwa.

Menurut Hendar Soetarna, nilai tinggi dari keterangan terdakwa merupakan hal yang logis, karena tidak mungkin keterangan dari orang yang melakukan, mengetahui secara lengkap baik saat

\footnotetext{
39 Ibid., hal. 81.

40 Ibid.

41 Ibid.

42 Undang-Undang No. 8 Tahun 1981 tentang Hukum Acara Pidana, op. cit.
} 
tindak pidana itu dilakukan, maupun persiapan tindak pidana, dan setelah tindak pidana dilakukan. ${ }^{43}$ Sehubungan dengan hasil pembuktian, keterangan terdakwa tidak hanya terbatas keterangan yang membenarkan dakwaan, keterangan penyangkalan juga tidak perlu dibuang dari hasil pembuktian, terlebih lagi jika alat bukti yang digelar di pemeriksaan tidak ada satupun yang mendukung penyangkalannya. Penyangkalan demikian juga tidak perlu diubah menjadi keterangan yang mengiyakan. ${ }^{44}$

\section{Pelanggaran Penyidik Dalam Upaya Memperoleh Keterangan Terdakwa}

Berdasarkan data pengaduan yang diterima LBH Jakarta, dari 37 korban sebanyak $5 \%$ atau 2 orang korban mengaku mendapatkan penyiksaan pada tahap penangkapan, bahkan 1 diantara 2 korban tersebut mengalami penyiksaan hingga meninggal dunia pada tahap penangkapan. $3 \%$ atau 1 orang korban penyiksaan mengaku mendapatkan penyiksaan pada tahap penahanan. Sementara $92 \%$ sisanya atau 34 orang lainnya menjadi korban penyiksaan pada saat proses pemeriksaan/interogasi. 45

Di sepanjang tahun 2013 s.d. 2016 terdapat Kepolisian melakukan penyiksaan di berbagai tingkatan, baik pada tingkat Kepolisian Sektor (POLSEK) sampai dengan Kepolisian Daerah (POLDA). Dari pengaduan yang diterima $\mathrm{LBH}$ Jakarta tersebut 5 korban penyiksaan dilakukan oleh Kepolisian yang tidak terindetifikasi dari tingkat apa, 3 korban penyiksaan dilakukan oleh Kepolisian pada tingkatan POLDA, 9 korban penyiksaan yang dilakukan oleh Kepolisian pada tingkatan Polsek dan 21 korban penyik-

\footnotetext{
${ }^{43}$ Hendar Soetarna, op. cit., hal. 100.

44 Ibid.

45 Ayu Eza Tiara, op. cit., hal. 44.
}

saan dilakukan oleh Kepolisian pada tingkat Polres. ${ }^{46}$

Seringkali perjuangan mengungkap kasus penyiksaan berujung buntu. Meskipun demikian, berbagai upaya terus ditempuh untuk memperjuangkan hak para korban penyiksaan dan mengubah arah kebijakan pencegahan dan penanganan kasus-kasus penyiksaan. ${ }^{47}$

Walaupun KUHAP dikatakan amat menghormati hak-hak tersangka/terdakwa, tindak kekerasan dalam penyidikan masih saja terjadi. Polisi masih menggantungkan proses penyidikan pada keterangan tersangka. 48 Sementara itu, ada pendapat yang mengatakan bahwa polisi menempuh "jalan pintas" dan berpacu dengan waktu dikarenakan sedikitnya anggaran dan kurangnya fasilitas yang dimiliki. Polisi sangat memfokuskan pada pengakuan tersangka dibandingkan dengan menemukan saksi dan bukti-bukti. 49

Setiap penyiksaan dan tindakan atau hukuman yang kejam, tak manusiawi, atau merendahkan martabat manusia merupakan pelanggaran HAM. Mereka yang dinyatakan sebagai tersangka pelaku tindak kejahatan juga dapat menjadi korban pelanggaran HAM. 50 Hal itu terjadi jika mereka mengalami penyiksaan selama dalam proses penyidikan ataupun dalam pembuatan Berita Acara Penyidikan. Dan kini, Indonesia telah meratifikasi Konvensi Anti Penyiksaan (Convention Against Torture and Other Cruel Inhuman or Degrading Treatment or Punishment) pada tahun 1998.51 Yang menjadi per-

\footnotetext{
46 Ibid., hal. 44-45.

47 Ibid., hal. 46.

48 Hukumonline.com, Kekerasan dalam Penyidikan, https://www.hukumonline.com/berita/bac a/hol2037/kekerasan-dalam-penyidikan/ diakses tanggal 9 Maret 2020.

49 Ibid.

50 Ibid.

51 Ibid.
} 
soalan adalah bagaimana mengawasi jaminan untuk tidak disiksa oleh petugas dalam masa penyidikan dalam prakteknya. Media massa sering mengangkat berita mengenai tersangka kejahatan yang mengalami siksaan. 52

Kepolisian kini dituntut untuk lebih profesional dalam menjalankan tugasnya. Mereka harus menanggalkan perasaan bahwa mereka pernah menjadi bagian dari militer. Mereka harus memahami prinsip dan nilai-nilai hak asasi manusia (HAM) dengan terus mengkaji dan membekali setiap personel polisi dengan pengetahuan dan pemahaman HAM yang memadai sesuai dengan standar internasional. 53

Polisi harus menyadari bahwa yang menentukan bersalah atau tidak seorang tersangka/terdakwa adalah hakim. Selain itu, yang juga perlu mendapat perhatian adalah sikap dari kalangan hakim. Masih banyak hakim yang "tidak berminat" untuk berani membatalkan BAP yang dibuat dengan cara-cara kekerasan. ${ }^{54}$

Kenyataan ini semakin membuat kesan bahwa cara-cara kekerasan dalam penyidikan dianggap sebagai sesuatu yang biasa dan diamini banyak pihak. Bahkan, dianggap sebagai suatu kewajaran kalau tidak mau dibilang sudah menjadi suatu keharusan. ${ }^{55}$

Dalam kasus pemeriksaan Dede Luthfi Alfiandi, 20 tahun, pemuda pembawa bendera yang viral saat demo di DPR mengaku dianiaya oleh penyidik kepolisian saat dimintai keterangan di Polres Jakarta Barat. Pernyataan itu, ia lontarkan saat memberikan kesaksian di hadapan hakim Pengadilan Negeri Jakarta Pusat, Senin (20/1/2020). Pada saat diperiksa di Polres Jakbar, ia dalam posisi duduk. Dia menceritakan terus-

\footnotetext{
52 Ibid.

53 Ibid.

54 Ibid.

55 Ibid.
}

menerus diminta untuk mengaku telah melempar batu kepada aparat kepolisian yang saat itu tengah mengamankan aksi di depan Gedung DPR/MPR. Jika tidak mau mengaku, penyidik tak segan-segan menyetrum tubuh Luthfi. Kupingnya dijepit, dan sekali-kali disuruh jongkok. Bahkan penganiayaan itu dilakukan secara terus-menerus agar ia mengakui. Padahal berdasarkan pernyataannya, Luthfi tidak melakukan perbuatan itu, sehingga tindakan kekerasan oleh aparat itu membuatnya terpaksa mengakui perbuatannya. ${ }^{56}$

Luthfi berani mengakui penganiayaan yang dilakukan oleh penyidik kepolisian karena dia dipaksa oleh hakim. katanya. Dalam aksi Reformasi Dikorupsi itu, Luthfi didakwa merusak fasilitas umum, melakukan pelemparan batu terhadap aparat keamanan, dan tak mengindahkan peringatan aparat. Dalam dugaan perbuatan nya itu, Luthfi didakwa dengan pasal 170, 212, 214, dan 218 KUHP. 57

Menurut Direktur Amar Law Firm, Alghiffari Aqsa tindakan yang dilakukan oleh penyidik kepolisian terhadap Luthfi. Menurutnya itu merupakan bentuk penyiksaan. Ia menilai, tindakan kepolisian itu melanggar Undang-undang Dasar (UUD) 1945, UU Hak Asasi Manusia (HAM), Konvenan Hak-hak Sipil dan Politik, dan Konvensi Anti Penyiksaan. Penganiayaan yang dilakukan oleh penyidik kepolisian, kata dia, tergolong merupakan pelanggaran HAM. ${ }^{58}$ Mantan Direktur Lembaga Bantuan Hukum (LBH) Jakarta itu menuturkan polisi yang melakukan penyiksaan terhadap Luthfi seharusnya bisa dihukum dengan pasal 422 KUHP dengan ancaman penjara maksimal dua tahun dan delapan bulan. Selain itu, polisi juga dapat dikenakan

56 Riyan Setiyawan, op. cit.

57 Ibid.

58 Ibid. 
perbuatan penganiayaan sesuai Pasal 351 KUHP. Jika menyebabkan luka berat terhadap korban, polisi bisa dikenakan pasal 351 ayat 2, pasal 353, pasal 354, dan pasal 355 KUHP. 59

Peneliti Institute for Security and Strategic Studies (ISESS), Bambang Rukminto melihat kekerasan yang dilakukan oleh penyidik kepolisian terhadap tersangka bukanlah cara yang asing. Tetapi ia menilai kekerasan yang dilakukan untuk mengejar pengakuan tersangka jauh dari kata manusiawi. 60 Menurut Bambang Rukminto, Kasus salah tangkap tak lepas dari kekerasan polisi yang masih menitikberatkan pada pengakuan tersangka dibanding mencari barang bukti. Polisi modern lebih fokus pada pencarian barang bukti. ${ }^{61}$

Selain kasus Luthfi, berdasarkan catatan YLBHI, selama melakukan riset dari 2005 hingga 2019, sebanyak 80 persen masyarakat mengalami kekerasan saat masuk di dalam ranah penyidikan kepolisian. Mereka mengalami penyiksaan baik fisik, psikis, bahkan kekerasan seksual. 62 Ketua Advokasi YLBHI, Muhammad Isnur mengatakan, Luthfi dan keluarganya dapat melaporkan anggota kepolisian yang melakukan tindak kekerasan ke Divisi Profesi dan Pengamanan (Propam) Polri.63

Namun, Polres Jakarta Barat membantah pihaknya melakukan penganiayaan, bahkan sampai menyetrum tubuh Luthfi saat melakukan pemeriksaan. 64 Humas Polres Jakarta Barat, Bripka Ashari menyatakan bahwa pihaknya telah melakukan pemeriksaan sesuai dengan

\footnotetext{
59 Ibid.

60 Ibid.

61 Ibid.

62 Ibid.

63 Ibid.

64 Ibid.
}

Standar Operasional Prosedur (SOP) terhadap Luthfi. 65

Institusi kepolisian bukan tidak menyadari bahwa penyiksaan itu merupakan pelanggaran. Komisaris Besar Iza Fadri mengatakan bahwa sebagai lembaga penegak hukum Polri tidak mentolerir anggotanya yang melakukan penyiksaan terhadap warga sipil. Kalau ada anggota yang terbukti melakukan penyiksaan bisa diseret ke peradilan umum. Polri tunduk pada peradilan umum. ${ }^{66}$

Secara internal, tindakan penyiksaan bisa juga berbuah hukuman indisipliner kepada polisi bersangkutan. Namun hingga kini penyiksaan yang dilakukan oleh polisi selama penyidikan belum bisa dipetakan secara kuantitatif. 67

Direktur Program LBH Masyarakat, Ricky Gunawan punya perspektif lain soal penyiksaan. Ia yakin penyiksaan masih sering terjadi. Cuma, korban enggan melapor atau mengadu ke polisi. Pertama, korban khawatir bahwa laporan mereka ke polisi mengenai penyiksaan yang dilakukan oleh polisi tak bakal ditindaklanjuti. Akan ada semacam semangat membela korps. Kedua, korban khawatir bila melapor, mereka malah akan mendapat penyiksaan yang lebih berat. Maklum, biasanya orang yang disiksa mendapat status tersangka dalam waktu bersamaan. 68

Bebas dari penyiksaan yang dilakukan aparat penegak hukum, menurut Papang Hidayat, Kepala Divisi Litbang Kontras, merupakan hak asasi semua orang. Jadi, tidak terbatas pada mereka

65 Ibid.

66 Hukumonline.com, Masih Sulit Memetakan Penyiksaan yang Dilakukan Penyidik, https://www.hukumonline.com/berita/bac a/hol21151/masih-sulit-memetakanpenyiksaan-yang-dilakukan-penyidik-/ diakses tanggal 9 Maret 2020.

67 Ibid.

68 Ibid. 
yang jadi tersangka, tetapi juga mereka yang sudah menjadi tahanan atau narapidana. Ke depan, seharusnya proses hukum serta bukti yang diperoleh dari penyiksaan dianggap ilegal. Konvensi Anti Penyiksaan dan Kovenan Internasional Hak-Hak Sipil dan Politik sudah mengarahkan demikian. Pasal 7 Kovenan tadi menyebutkan ketentuan pelarangan praktik penyiksaan di setiap proses penegakan hukum tanpa disertai definisi baku soal penyiksaan. Selanjutnya pasal 15 Kovenan menyebut: Setiap negara pihak harus menjamin bahwa setiap pernyataan yang dibuat sebagai tindak lanjut dari penyiksaan harus tidak digunakan sebagai bukti. 69

Menurut Komisioner Komisi Kepolisian Nasional (Kompolnas) Poengky Indarti, jangankan menggunakan cara kekerasan, memaksa seseorang mengaku telah melakukan tindak pidana saja kepolisian tidak diperbolehkan. ${ }^{70}$ Jika ada dugaan polisi yang menangkap dan memeriksa melakukan penyiksaan, Poengky menyarankan kepada korban untuk segera melapor kepada Kadiv Propam. Propam harus langsung memproses perkara tersebut untuk mencari tahu benar tidaknya kabar penyiksaan. Menurut Poenky, jika pemeriksaan Propam mengindikasikan terjadi tindak pidana, maka tidak hanya sidang disiplin maupun kode etik saja, melainkan dapat diserahkan ke Reskrim untuk diproses pidana. ${ }^{71}$

Poengky menjelaskan, hukuman yang dikenakan kepada oknum polisi yang melakukan kekerasan dalam proses interogasi beragam. Apabila penganiayaan

69 Ibid.

70 Jay Akbar, Polisi Tidak Boleh Melakukan Kekerasan Saat Menginterogasi, Tirto.id, https://tirto.id/polisi-tidak-bolehmelakukan-kekerasan-saatmenginterogasi-csS6, diakses tanggal 10 Maret 2020.

71 Ibid. berat, misalnya mengakibatkan kematian, maka pelaku tidak hanya dipenjara, tetapi juga bisa diberhentikan tidak dengan hormat (PTDH). ${ }^{72}$

Pengamat kepolisian dari Institute for Security and Strategic Studies (ISESS) Bambang Rukminto mengatakan polisi tidak mungkin memberi sanksi berat terhadap sesama anggota. Meskipun, prosedur untuk melaporkan polisi yang berbuat kesalahan selama proses penyidikan itu ada. Bambang menyatakan bahwa secara prosedur memang harus dilaporkan pada Propam atau Irwasum. Bambang juga menyatakan bahwa hukuman bagi polisi yang melakukan kekerasan pun masih tertutup di internal mereka, rata-rata hanya terbatas sanksi etik. ${ }^{73}$

Bambang menilai belum ada lembaga eksternal yang independen dan berani mengawasi cara polisi dalan menyelidiki suatu kasus tindak pidana. Polisi hanya memiliki lembaga internal yang mengawasi suatu penyelidikan kasus tindak pidana. Oleh karena itu, anggota polisi masih rentan melakukan aksi kekerasan untuk menekan seseorang mengakui perbuatan tindak pidana. ${ }^{74}$

Menurut M. Yahya Harahap dalam bukunya "Pembahasan Permasalahan dan Penerapan KUHAP - Penyidikan dan Penuntutan", terdakwa berhak untuk memberi keterangan yang dianggap terdakwa paling menguntungkan baginya. Jadi, seorang terdakwa berhak untuk

72 Ibid.

73 Rindi Nuris Velarosdela, Polisi Dilaporkan Atas Kekerasan Saat Penyelidikan, Pengamat Sebut Jeruk Tak Mungkin Makan Jeruk, Kompas.com, https://megapolitan.kompas.com/read/20 19/07/19/19183241/polisi-dilaporkanatas-kekerasan-saat-penyelidikanpengamat-sebut-jeruk?page $=$ all diakses tanggal 10 Maret 2020.

74 Ibid. 
membantah dalil-dalil yang diajukan dalam dakwaan dan memberikan keterangan yang menguntungkan bagi dirinya. Dalam teori hukum pidana, asas ini disebut non self incrimination, yaitu seorang terdakwa berhak untuk tidak memberikan keterangan yang akan memberatkan/merugikan dirinya di muka persidangan. ${ }^{75}$

Menurut pasal 175 KUHAP, jika terdakwa tidak mau menjawab atau menolak untuk menjawab pertanyaan yang diajukan kepadanya, hakim ketua sidang menganjurkan terdakwa untuk menjawab, dan setelah itu pemeriksaan dilanjutkan. Jadi, terdakwa diperbolehkan untuk tidak menjawab atau menolak menjawab pertanyaan yang diajukan padanya. Dalam hal ini terjadi, hakim ketua sidang menganjurkan pada terdakwa agar menjawab. Tidak ada sanksi bagi terdakwa yang menolak menjawab demikian. ${ }^{76}$

\section{Pencegahan Tindak Kekerasan Di Dalam Pelaksanaan Penyidikan}

Kapolresta Yogyakarta Kombes Pol Armaini mengatakan soal kesalahan prosedur dalam penindakan hukum diakui dia memang bisa saja terjadi. Ia juga mempersilakan jika memang merasa dirugikan kemudian melakukan laporan ${ }^{77}$ (ke Propam-penulis-).

Pengungkapan suatu tindak pidana tidak mempedomani pengakuan Tersangka tetapi yang terpenting adalah memperoleh alat-alat bukti. Jadi, meskipun Tersangka mengingkari seluruh persangkaan kepadanya, itu tidak menjadi soal

75 Shanti Rachmadsyah, Hak untuk Mungkir, https://www.hukumonline.com/klinik/det ail/ulasan/cl4616/hak-untuk-mungkir/, diakses tanggal 19 Maret 2020.

76 Ibid.

77 Irwan Syambudi, Mahasiswa Jogja Korban Salah Tangkap: Babak Belur Dipukul Polisi, https://tirto.id/ep2G diakses tanggal 9 Maret 2020. sepanjang alat bukti sudah dipegang oleh Penyidik. Sebaliknya, meskipun tersangka atau terperiksa mengakui segala perbuatannya tetapi bukti-bukti tidak ada maka tersangka atau terperiksa tidak dapat dijerat. ${ }^{78}$

Namun demikian, masih banyak Petugas Kepolisian yang memperlakukan terperiksa sebagai objek dan melakukan kekerasan. Konsekuensi hukum dari tindakan tersebut, Hakim di persidangan dapat membebaskan terdakwa karena segala keterangan didapat dari hasil penyiksaan dan intimidasi. Yurisprudensi MARI No. 1174K/Pid/1994 tanggal 3 Mei 1995 (kasus Marsinah) dalam pertimbangannya Mahkamah Agung membebaskan para Terdakwa karena keterangan yang diberikan di depan Penyidik ternyata penuh tekanan fisik dan psikis. ${ }^{79}$

Bagi tersangka atau terperiksa yang mengalami kekerasan sehingga memberikan pengakuan atas persangkaan yang tidak diperbuatnya, sepanjang dapat dibuktikan benar ada kekerasan maka hal itu dapat diajukan di Persidangan. Hakim dapat mengenyampingkan nilai pembuktian atas fakta-fakta yang ada di dalam Berita Acara Pemeriksaan (BAP) jika benar dapat dibuktikan kekerasan itu. Yurisprudensi MARI No. 1615K/Pid/1989, tertanggal 16 September 1992 menyatakan keterangan Terdakwa dalam BAP Kepolisian yang kemudian ditarik kembali dalam suatu persidangan, dengan alasan yang logis, maka penarikan keterangan tersebut adalah sah, sehingga keterangan Terdakwa dan saksi dalam BAP tersebut tidak mempunyai nilai pembuktian menurut KUHAP. 80

\footnotetext{
78 Litigasi.co.id, Kekerasan Terhadap Tersangka Dan Akibat Hukumnya, https://litigasi.co.id/kekerasan-terhadaptersangka-dan-akibat-hukumnya, diakses tanggal 9 Maret 2020.

79 Ibid.

80 Ibid.
} 
Metode pemeriksaan dengan menggunakan kekerasan fisik maupun psikis harus ditinggalkan di dalam praktek penegakan hukum. Banyak efek yang ditimbulkan dari tindakan kekerasan tersebut diantaranya terjadinya peradilan sesat yang menghukum orang yang tidak bersalah. Penegakan hukum harus secara jujur dan murni berdasarkan bukti-bukti yang kuat dan tidak diragukan validasinya. 81

Penyidik diharapkan dapat menempuh pendekatan yang lebih manusiawi dalam mencari keterangan tersangka untuk dibuat berita acaranya. Banyak cara yang dapat ditempuh untuk mendapatkan keterangan tersangka dengan baik dan bermartabat. Salah satu caranya adalah dengan melakukan pendekatan secara psikologis.

Fungsi dan peranan psikologi dalam bidang hukum dapat dibagi dalam tiga jenis, pertama psikologi dapat digunakan untuk menguji kebenaran praanggapan yang digunakan dalam hukum itu sendiri, kedua digunakan dalam proses hukum dan ketiga digunakan dalam sistem hukum itu sendiri. ${ }^{82}$ Penerapan psikologi dalam hukum yang didasarkan pada fungsi psikologi tersebut pada dasarnya adalah berkaitan dengan hak-hak asasi tersangka sebagai pihak yang sedang dibatasi kebebasannya. ${ }^{83}$

Penyidik yang menguasai, minimal mengetahui sedikit psikologi, dapat dengan mudah mengenal watak, pribadi tersangka, sehingga dapat ditentukan teknik-teknik pendekatan yang cocok untuk keberhasilan pemeriksaan yang

81 Ibid.

82 Siska Diana Sari, Pentingnya Penguasaan Psikologi Bagi Penyidik dalam Pemeriksaan Tersangka pada Tahap Penyidikan, (Suatu Tinjauan Yuridis dan Psikologi). (2016). Jurnal Universitas PGRI Madiun.

83 Ibid. berlangsung secara manusiawi. ${ }^{84}$ Ketika mencari keterangan dari tersangka seorang penyidik perlu menerapkan salah satu atau beberapa dari bidang-bidang yang terdapat dalam psikologi yang dianggap paling tepat untuk membantu kelancaran tugasnya, seperti penerapan dibidang psikologi kepribadian atau tipologi apabila melihat tujuan dari psikologi kepribadian atau tipologi adalah untuk melihat mempelajari kepribadian, ciri-ciri, tipe-tipe seseorang. ${ }^{85}$

Kelancaran dalam menarik keterangan dari tersangka adalah tergantung dari kemampuan dan kepandaian penyidik dalam menerapkan taktik dan teknik penyidikan. Oleh karenanya, penguasaan terhadap bidang- bidang dalam psikologi tersebut di atas dilengkapi dengan pengusaan dalam bidang wawancara, karena metode tersebut ikut memegang peranan penting dalam kelancaran pemeriksaan tersangka. Dengan teknikteknik wawancara, terutama keahlian dalam menyusun pertanyaan-pertanyaan yang diajukan, merupakan alat bantu yang sangat penting. Dengan alat ini bisa diadakan pendekatan dengan mengajak tersangka berdialog, berdiskusi, mengajukan pertanyaan-pertanyaan dengan santai tetapi lancar sehingga tersangka maupun penyidik tidak akan mudah terpancing emosi. Di dalam pemeriksaan, seringkali penyidik memperingatkan tersangka, karena dinilainya tersangka berbelit-belit dalam menyampaikan keterangannya. Dalam keadaan bagaimanapun penyidik harus bisa menahan emosi. Di sinilah arti pentingnya pendekatan oleh penyidik terhadap tersangka dengan alat bantu psikologi. 86

Seorang penyidik harus berbicara sedikit, tegas, terang tetapi jangan meninggalkan kesopanan dan keramahan,

84 Ibid.
85 Ibid.
86 Ibid. 
bersikap kekeluargaan, ramah dan menarik. Apabila tersangka mempunyai perasaan takut, harus bersifat membimbing dan terhadap tersangka yang sombong, lebih baik memuji dan menyanjungnya. Keadaan tersebut akan membuat tersangka merasa diperhatikan sebagai subyek yang mempunyai hak dan kewajiban. Dari situasi yang baik inilah, tersangka akan memberikan jawaban atau keterangan yang sebenarnya dan sejujurnya. 87

Keterangan tersangka memang sangat diperlukan, tetapi tidak berarti harus diperoleh dengan jalan pintas yang kasar. Untuk mendapatkan keterangan yang jujur dan benar, seorang penyidik dapat menerapkan salah satu bidang ilmu bantu dalam rangka penegakkan hukum, yaitu psikologi. Psikologi lebih berpijak pada pengetahuan tentang manusia, khususnya tentang perilaku dan perbuatan manusia dalam hubungannya dengan lingkungannya. Dengan dibantu psikologi, dapatlah seorang penyidik memperoleh keterangan dari tersangka dengan mudah, karena telah dapat dilakukan pendekatan pribadi (personal approach) yang manusiawi. Dengan demikian penggunaan psikologi dalam pemeriksaan tersangka merupakan satu tahap langkah kemajuan bagi dunia penegak hukum, 88 maka perlu diadakan kerjasama antara aparat atau instansi penegak hukum, khususnya Kepolisian Negara Republik Indonesia dengan pihakpihak yang berkecimpung dalam psikologi, yaitu para psikolog. 89

Dalam kasus pembunuhan Wayan Mirna Salihin yang menempatkan Jessica sebagai tersangka dan terdakwa, penyidik berhasil membuat BAP yang pada intinya menyatakan bahwa Jessica Kumala Wongso melakukan pembunuhan dengan

87 Ibid.

88 Ibid.

89 Ibid. menuangkan sianida ke dalam kopi yang kemudian diminum oleh Mirna. Jessica sama sekali tidak mengakui perbuatannya dslsm BAP maupun di persidangan. 90

Pada akhirnya, majelis hakim menjatuhkan hukuman penjara pada Jessica yaitu pidana penjara selama 20 tahun. ${ }^{91}$ Hal ini membuktikan bahwa sebetulnya penyidik mampu menjerat pelaku tindak pidana meskipun mereka diam, menyang$\mathrm{kal}$, atau pun berbelit-belit dalam memberikan keterangan terkait perbuatan pidananya dengan menggunakan empat alat bukti selain keterangan terdakwa. Terlepas dari fakta bahwa Jessica adalah perempuan dan kemungkinan penyidik enggan menggunakan kekerasan terhadap dirinya, seharusnya hal ini juga mampu diterapkan kepada semua tersangka apapun jenis kelaminnya.

\section{PENUTUP}

Dari pembahasan di atas, penulis membuat kesimpulan sebagai berikut:

1. Terdapat sejumlah kasus penganiayaan yang dilakukan oleh penyidik kepada tersangka pelaku tindak pidana, padahal dari pengalaman kasus pembunuhan Wayan Mirna Salihin, diketahui bahwa penyidik dan aparat penegak hukum yang lain mampu menjatuhkan putusan pidana

90 Nafiysul Qodar, Jessica: Siapa pun dan Apa pun Tak Bisa Membuat Saya Mengaku, https://www.liputan6.com/news/read/26 24479/jessica-siapa-pun-dan-apa-pun-takbisa-membuat-saya-mengaku, diakses tanggal 18 Maret 2020.

91 Nursita Sari, PK Ditolak MA, Jessica Kumala Wongso Tetap Dihukum 20 Tahun Penjara. https://megapolitan.kompas.com/read/20 18/12/31/12441571/pk-ditolak-majessica-kumala-wongso-tetap-dihukum-20tahun-penjara, diakses tanggal 19 Maret 2020. 
penjara selama 20 tahun tanpa adanya tindak kekerasan terhadap tersangka.

2. Beberapa tersangka yang dianiaya polisi dengan tujuan untuk mendapat keterangan terkait tindak pidana yang dilakukan enggan melapor ke Propam.

3. Sanksi yang dapat dikenakan pada penyidik yang menganiaya tersangka dapat berupa sanksi pidana dan/atau sanksi etik. Polri tunduk kepada hukum, oleh karena itu, penganiayaan yang dilakukan kepada tersangka setidaknya dapat dikenakan pasal 351 KUHP tentang penganiayaan.

4. Dari sisi tersangka atau terdakwa, menurut pasal 175 KUHAP, walaupun tersangka dianjurkan untuk menjawab pertanyaan hakim, namun tidak ada sanksi yang dijatuhkan apabila tersangka menolak.

5. Salah satu metode penyidikan yang disajikan dalam tulisan ini adalah melalui pendekatan psikologis secara manusiawi. Dengan ini diharapkan tersangka dapat lebih terbuka untuk memberikan keterangan dengan bebas.

Berdasarkan kesimpulan di atas, penulis merekomendasikan beberapa hal sebagai berikut:

1. Kepolisan diharap untuk mereduksi tindak penganiayaan terhadap tersangka dengan menggunakan empat alat bukti selain keterangan terdakwa apabila tersangka tidak kooperatif.

2. Jika penganiayaan terhadap tersangka masih terjadi, diharapkan tersangka yang disidik melapor ke Propam dengan didampingi advokat dengan menunjukkan bukti-bukti penganiayaan.

3. Terhadap penyidik yang melakukan penganiayaan, jika memang terbukti, hendaknya diberi sanksi etik dan juga sanksi pidana sesuai peraturan perundang-undangan yang berlaku.
Hal ini untuk menciptakan rasa keadilan dan mengkondusifkan proses penyidikan selanjutnya.

4. Perlunya pelatihan dasar mengenai psikologi kriminal bagi para penyidik untuk membaca keadaan jiwa pelaku tindak pidana, atau dapat juga bekerjasama dengan psikolog atau psikiater untuk membantu proses penyidikan yang bersih dan manusiawi.

\section{DAFTAR PUSTAKA}

\section{Buku}

Ayu Eza Tiara, dkk., Kepolisian dalam Bayang-Bayang Penyiksaan (Catatan Kasus Penyiksaan Sepanjang Tahun 2013 s.d. 2016. Jakarta. Lembaga Bantuan Hukum Jakarta. Tanpa tahun.

Dio Ashar Wicaksana, Penyiksaan Penyidik terhadap Terdakwa untuk Mendapatkan Pengakuan, Anotasi Putusan, No. Register Perkara 1131/Pid. An/2013/PN.Jkt.Sel, MaPPI FHUI, 2016.

Hamzah, Andi. Hukum Acara Pidana Indonesia, Edisi Kedua. Cet. 8. Jakarta. Sinar Grafika. 2017.

Soetarna, Hendar. Hukum Pembuktian dalam Acara Pidana, Cet. 3. Bandung. Alumni. 2019.

\section{Internet}

Hukumonline.com, Kekerasan dalam Penyidikan, https:// www.hukumonline.com/berita/ba ca/hol2037/kekerasan-dalampenyidikan/ diakses tanggal 9 Maret 2020. 
Hukumonline.com, Masih Sulit Memetakan Penyiksaan yang Dilakukan Penyidik, https://www.hukumonline.com/b erita/baca/hol21151/masih-sulitmemetakan-penyiksaan-yangdilakukan-penyidik-/ diakses tanggal 9 Maret 2020.

Irwan Syambudi, Mahasiswa Jogja Korban Salah Tangkap: Babak Belur Dipukul

Polisi, https://tirto.id/ep2G diakses tanggal 9 Maret 2020.

Jay Akbar, Polisi Tidak Boleh Melakukan Kekerasan Saat Menginterogasi, Tirto.id, https://tirto.id/polisitidak-boleh-melakukankekerasan-saat-menginterogasicsS6, diakses tanggal 10 Maret 2020.

Litigasi.co.id, Kekerasan Terhadap Tersangka Dan Akibat Hukumnya, https://litigasi.co.id/kekerasanterhadap-tersangka-dan-akibathukumnya, diakses tanggal 9 Maret 2020.

Nafiysul Qodar, Jessica: Siapa pun dan Apa pun Tak Bisa Membuat Saya Mengaku, https://www.liputan6. $\mathrm{com} / \mathrm{news} / \mathrm{read} / 2624479 /$ jessica -siapa-pun-dan-apa-pun-tak-bisamembuat-saya-mengaku, diakses tanggal 18 Maret 2020.

Nursita Sari, PK Ditolak MA, Jessica Kumala Wongso Tetap Dihukum 20 Tahun Penjara. https://megapolitan.kompas.com $\angle \mathrm{read} / 2018 / 12 / 31 / 12441571 / \mathrm{pk}$ -ditolak-ma-jessica-kumalawongso-tetap-dihukum-20-tahunpenjara, diakses tanggal 19 Maret 2020.
Rindi Nuris Velarosdela, Polisi Dilaporkan Atas Kekerasan Saat Penyelidikan, Pengamat Sebut Jeruk Tak Mungkin Makan Jeruk, Kompas.com, https://megapolitan.kompas.com $\angle \mathrm{read} / 2019 / 07 / 19 / 19183241 / \mathrm{po}$ lisi-dilaporkan-atas-kekerasansaat-penyelidikan-pengamatsebut-jeruk? page $=$ all diakses tanggal 10 Maret 2020.

Riyan Setiawan, (2020-01-22). Kesaksian Lutfi Dianiaya Penyidik: Bukti Polisi Humanis Cuma Jargon. Tirto.id. https://tirto.id/kesaksian-lutfidianiaya-penyidik-bukti-polisihumanis-cuma-jargon-et6L diakses tanggal 24 Februari 2020.

Shanti Rachmadsyah, Hak untuk Mungkir, https://www.hukumonline.com/k linik/detail/ulasan/cl4616/hakuntuk-mungkir/, diakses tanggal 19 Maret 2020.

\section{Peraturan Perundang-undangan}

Undang-Undang No. 8 Tahun 1981 tentang Hukum Acara Pidana.

\section{Jurnal}

Siska Diana Sari, Pentingnya Penguasaan Psikologi Bagi Penyidik dalam Pemeriksaan Tersangka pada Tahap Penyidikan, (Suatu Tinjauan Yuridis dan Psikologi). (2016). Jurnal Universitas PGRI Madiun 